Florida International University FIU Digital Commons

$3-5-2015$

\title{
Nothing Normal Happens to Me: True Stories of a Journey from Madness to Motherhood
}

Esther C. Martinez

Florida International University, emart042@fiu.edu

DOI: $10.25148 /$ etd.FI15032108

Follow this and additional works at: https://digitalcommons.fiu.edu/etd

Part of the Nonfiction Commons

\section{Recommended Citation}

Martinez, Esther C., "Nothing Normal Happens to Me: True Stories of a Journey from Madness to Motherhood" (2015). FIU

Electronic Theses and Dissertations. 1934.

https://digitalcommons.fiu.edu/etd/1934

This work is brought to you for free and open access by the University Graduate School at FIU Digital Commons. It has been accepted for inclusion in FIU Electronic Theses and Dissertations by an authorized administrator of FIU Digital Commons. For more information, please contact dcc@fiu.edu. 


\section{FLORIDA INTERNATIONAL UNIVERSITY}

Miami, Florida

NOTHING NORMAL HAPPENS TO ME:

TRUE STORIES OF A JOURNEY FROM MADNESS TO MOTHERHOOD

A thesis submitted in partial fulfillment of

the requirements for the degree of

MASTER OF FINE ARTS

in

CREATIVE WRITING

by

Esther Martinez 
To: Dean Michael R. Heithaus

College of Arts and Sciences

This thesis, written by Esther Martinez, and entitled Nothing Normal Happens to Me: True Stories of a Journey from Madness to Motherhood, having been approved in respect to style and intellectual content, is referred to you for judgment.

We have read this thesis and recommend that it be approved.

Debra Dean

Bruce Harvey

Les Standiford, Major Professor

Date of Defense: March 5, 2015

The thesis of Esther Martinez is approved.

Dean Michael R. Heithaus
College of Arts and Sciences

Dean Lakshmi N. Reddi University Graduate School

Florida International University, 2015 
(C) Copyright 2015 by Esther Martinez

All rights reserved. 


\begin{abstract}
OF THE THESIS
NOTHING NORMAL HAPPENS TO ME:

TRUE STORIES OF A JOURNEY FROM MADNESS TO MOTHERHOOD

by

Esther Martinez
\end{abstract}

Florida International University, 2015

Miami, Florida

Professor Les Standiford, Major Professor

Written in first person, NOTHING NORMAL HAPPENS TO ME is a memoir in essays that traces the narrator’s journey from self-destruction to creation. Part one encompasses the narrator's lost years, after she breaks free from the tyranny of her mentally ill mother and goes to live on her own at 17. Part two provides context for those bad girl years, exploring her childhood when she identified with her histrionic mother. Part three comprises stories about the narrator's years of awakening when she seeks out transcendence, faith, and a family of her own. The pieces vary tonally and stylistically as they attempt to trace the maturing voice of the narrator. Like SEEKING RAPTURE:

SCENES FROM A WOMAN'S LIFE by Kathryn Harrison, this collection centers on a young girl, who without her mother's love, struggles to love herself. It is both a cautionary tale and a story of redemption. 


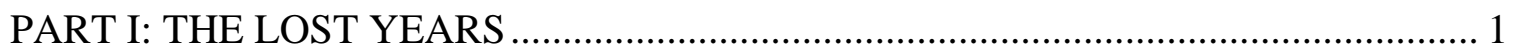

Lessons in Survival............................................................................................. 2

Protection ..........................................................................Error! Bookmark not defined.

The Evolution of a Storm..............................................Error! Bookmark not defined.

Numb .............................................................................Error! Bookmark not defined.

PART II: HALF NORMAL .................................................Error! Bookmark not defined.

Poaching Memories .......................................................Error! Bookmark not defined.

Helping Ourselves............................................................Error! Bookmark not defined.

Telenovelas .......................................................................roror! Bookmark not defined.

Honor Your Father..........................................................Error! Bookmark not defined.

Sex Education ..................................................................Error! Bookmark not defined.

Hunger ..............................................................................Error! Bookmark not defined.

The Eighth Orisha ...........................................................Error! Bookmark not defined.

Fall Fashion........................................................................Error! Bookmark not defined.

Half Normal ...................................................................Error! Bookmark not defined.

Moving ..............................................................................

PART III: AWAKENINGS .................................................Error! Bookmark not defined.

Meeting My Mother ........................................................Error! Bookmark not defined.

Born Again, Again .........................................................Error! Bookmark not defined.

Drama..............................................................................

Expecting .....................................................................Error! Bookmark not defined.

Birthday Girl ...................................................................Error! Bookmark not defined.

The Big Picture .................................................................Error! Bookmark not defined. 
PART I: THE LOST YEARS 


\section{Lessons in Survival}

When I was maybe ten, my mother told me she had been raped when she was fifteen. She said one of my grandfather's friends had offered her a ride home one day and though her father had warned her to not get "too close” to this particular man, she had accepted the ride.

“I thought I was old enough to make my own choices,” my mother said.

When the man made an unexpected stop at his apartment and asked my mother to come upstairs, she initially said no.

“Don’t tell me you're afraid,” he’d said.

“I didn’t want to be afraid,” my mother told me. "I wanted to be all grown up.” So she followed him upstairs.

“I was stupid,” my mother said. And that was really all I heard: not that she had made a stupid choice, but that she was stupid. Like the child I was, I didn't understand why she wanted to share this lesson with me since, after all, I was not stupid. I knew better.

The clouds were ominous. Dark, low-hanging, they roiled. And then suddenly, it was raining, an angry downpour of diagonal streaks that clattered when they hit the pavement. Without an umbrella, I was huddling under the bus stop shelter, waiting for the S bus to take me to my job at the Holiday Inn. My pantyhose were already soaked, and I could feel my feet squishing around inside my sneakers. Inside, I was starting to roil myself. Why did everything have to be a struggle for me? Why did I have to work a full- 
time job while the other kids in my high school were hanging out at the mall? Why couldn't I count on my mother for anything, not even a ride to work? I was positive that within minutes I would be completely drenched and then I'd have to sit on a freezing cold bus for 45 minutes only to arrive at work with a full eight-hour shift ahead of me and already looking like I’d survived a hurricane.

A white Toyota Corolla honked as it passed me. Thank God! It was my coworker, Peter. I waved at the car and it pulled over half a block up across the street. I made a run for it, splashing through the monsoon to where the passenger door was opening for me. I had already climbed inside and slammed the door shut behind me when I looked up and realized it was not Peter’s car. It was not Peter.

“Oh my God,” I said. "I thought you were my friend.”

“Where you going?” the man asked in a Spanish accent. Argentinean, I thought. “My mistake,” I said, opening the door to get out. "I'm just waiting for the bus to work."

"Is raining very much,” he said. "Where is your work? I can take you."

I knew I should not take a ride from this stranger, but the alternative was to go back out into the deluge. While I was deliberating, the S bus rolled past.

"Shit. There goes my bus."

"I can take you," the man said again. He looked me straight in the eyes. His voice betrayed no malice. I stayed put and closed the car door. 
Around the same time I learned of my mother's rape, I watched a TV special about how to survive dangerous situations. I learned that to escape from a car that has been submerged, you need to let it fill up with water before you open the doors. I learned that if you are confronted by a wild animal, you should resist the urge to run and instead be still, crouch, or play dead. I learned that most people who drown in a rip current do so not because they can’t swim, but because they lose control. Rip currents don’t pull you under; they only pull you away from the shore. If you panic and try to swim against the tide, you exhaust yourself and drown. The key is to swim with the current, along the shore. Go with the flow.

I might never have to face a submerged car or a bear attack or a rip tide, but the lessons had stuck in my mind and became a metaphor I conjured up whenever I perceived danger: I had to relinquish a little control to stay in control. The most dangerous thing I could do in a survival situation was to panic.

So when I was sitting in that car with a total stranger, I went with the flow. I knew men always wanted something. I knew what it was, and I didn't care. At seventeen, I told myself that as long as what they wanted was something I had, then I had some power, and power meant control. What was the worst that could happen? If he tried anything funny, I would go straight for his balls. While he was reeling from pain and trying to keep the car from skidding off the wet streets, I'd push the door open and roll out. Simple. I prepared myself for the possibility that this could really happen. After all, this was not Wichita, it was Miami. And this man had seen a teenage girl on the street, 
honked his car, and offered her a ride. I was careless and impulsive. But, I thought, I was not naïve.

His name was Ronaldo. As he drove, I watched Ronaldo’s hands, expecting at any moment they would do something inappropriate. I watched the crotch of his pants for any movement. My work uniform was a mint-green pencil skirt I'd had tailored to make it as snug and as short as HR would allow, and a white button-down shirt that had become damp and clung to my bra. I tugged at it. But Ronaldo’s eyes never left the road and his hands never left the steering wheel.

He made small talk. He wanted to know how old I was and if I went to school. I answered his questions honestly. I told him more than he asked to fill the awkward silence, but also to sound like an adult about the whole thing. I was seventeen. Almost eighteen. I worked full time, and yes, I also went to school. I was a senior at Miami Beach Senior High, but I was only taking four hours of classes because I had all the credit hours I needed to graduate plus tons of AP credits, and I didn’t want to spend any more time in that place than I had to. The other kids were so immature. So stupid.

I didn't ask Ronaldo anything about himself, but he told me anyway. He was married and had two daughters. One of them, my age.

We pulled up the ramp to the hotel entrance. Ronaldo stopped the car and said, "Here you are. It was nice meeting you, young lady.” Cuidate. "Take care of yourself.” I thanked Ronaldo and waved good-bye, and that night at work I told Peter about my accidental hitchhike. 